\title{
VERBAL MARKERS OF THE CONCEPT OF PEACE: PSYCHOLINGUISTIC AND LEXICAL ANALYSES
}

\author{
Iryna Melnyk \\ https://orcid.org/0000-0001-5946-0261 \\ melnyk.iryna@vnu.edu.ua \\ Lesya Ukrainka Volyn National University, Ukraine \\ Larysa Holoiukh \\ https://orcid.org/0000-0002-6971-6301 \\ lara2709@ukr.net \\ Lesya Ukrainka Volyn National University, Ukraine \\ Diana Kalishchuk \\ https://orcid.org/0000-0003-1952-5176 \\ dianakalishchuk@vnu.edu.ua \\ Lesya Ukrainka Volyn National University, Ukraine \\ Iryna Levchuk \\ https://orcid.org/0000-0002-8623-7425 \\ levchuk.iryna@vnu.edu.ua \\ Lesya Ukrainka Volyn National University, Ukraine
}

Received June 3, 2020; Revised August 8, 2020; Accepted September 4, 2020

\begin{abstract}
The paper is an attempt to uncover the associative semantics of the concept of 'Peace' as reflected in the Ukrainian national linguistic world image. The goal of the article is to carry out a psycholinguistic analysis of the concept's verbal markers and to compare its associative and lexical meanings at the current stage of the Ukrainian language development. Free word association test involved 148 first- and second-year students of Lesya Ukrainka Volyn National University (Ukraine), Faculty of Philology and Journalism, Ukrainian native speakers aged 18-20. It has been proved that responses related to common lexical meanings of the wordstimulus 'Peace' recorded in modern explanatory dictionaries are predominant. 105 wordsresponses have become the object of the analysis - 329 word-tokens in total, out of which 44 words have been used two times or more (from 2 to 59 times - 268 word-tokens in total), 61 words have been used one time only. The received responses have been differentiated according to semantic and grammatical criteria. Traditional responses which coincide with the common lexical meaning, as well as new original responses which reflect the respondents' individual experience and are non-typical (not recorded in the dictionaries), were received. The semantic principle of the concept of 'Peace' words-markers' systematization was used as the basis of forming 11 lexical semantic groups. Among the most numerous are the names related to the state of environment, people's inner world, their physical, emotional and mental state, moral
\end{abstract}

(C) Melnyk, Iryna; Holoiukh, Larysa; Kalishchuk, Diana; Levchuk, Iryna, 2020.

This is an Open Access article distributed under the terms and conditions of the Creative Commons Attribution 4.0 International Licence (http://creativecommons.org/licenses/by/4.0).

East European Journal of Psycholinguistics, 7(2), 214-230. https://doi.org/10.29038/eejpl.2020.7.2.mel 
and aesthetic properties $(47.1 \%)$; names that verbalize relations between people, nations, states $(31.9 \%)$. The groups of semantically distant responses are mainly represented by the names of concrete names, less frequently - by the names of abstract concepts and integral syntactic structures, which have no relation to any of the lexical meanings recorded in lexicographic sources. Their semantic ties can be traced at the unconscious level which reflects the psycholinguistic meaning of this word. The conducted word association test enabled defining the extension of the concept's psycholinguistic meaning and thus to record new fragments of the Ukrainian linguistic world image caused by historical, political, and national mental processes.

Keywords: concept of Peace, free word association test, psycholinguistic analysis, lexical analysis.

Мельник Ірина, Голоюх Лариса, Каліщук Діана, Левчук Ірина. Вербальні репрезентанти концепту Мир: психолінгвістичний та лексичний аналіз.

Анотація. У статті поглиблено дослідження асоціативної семантики концепту МИР у контексті української національно-мовної картини світу. Мета статті - здійснити психолінгвістичний аналіз вербальних репрезентантів концепту МИР та зіставити його асоціативне та лексичне значення на сучасному етапі розвитку української мови шляхом вільного асоціативного експерименту, до якого залучено 148 респондентів - студентів 1 та 2 курсів факультету філології та журналістики Волинського національного університету імені Лесі Українки, носіїв української мови, віком 18-20 років. Доведено, що істотно переважають асоціації, співвідносні з загальномовними лексичними значеннями словастимулу МИР, зафіксованими в сучасних тлумачних словниках. Об'єктом аналізу стали 105 слів-реакцій - 329 слововживань, із-поміж них 44 слова зафіксовані двічі і більше (від 2 до 59 разів - усього 268 слововживань), 61 слово - лише один раз. Одержані реакції диференційовано за семантичним та граматичним критерієм. Зафіксовано традиційні реакції респондентів, що збігаються з загальномовним значенням, та нові, оригінальні реакції, які відбивають індивідуальний досвід респондентів i $\epsilon$ нетиповими (не зафіксованими в словниках). Семантичний принцип систематизації слів-маркерів концепту МИР покладено в основу формування 11 лексико-семантичних груп, найчисельнішими 3 яких $\epsilon$ назви, пов'язані зі станом навколишнього середовища, внутрішнім світом людини, iii фізичним, емоційно-психічним станом, морально-етичними якостями $(47,1 \%)$; назви, що вербалізують відносини між особами, народами, державами $(31,9 \%)$. Виділено також групи семантично віддалених асоціацій переважно репрезентованих назвами конкретних, зрідка - абстрактних понять і цілісними синтаксичними конструкціями, які не співвідносні 3 жодним його лексичним значенням, зафіксованим у лексикографічних працях. Їхній змістовий зв'язок простежено на підсвідомому рівні, що віддзеркалює психолінгвістичне значення цього слова. Проведений експеримент дав змогу виявити розширення психолінгвістичного значення концепту МИР, а отже, зафіксувати нові фрагменти української мовної картини світу, зумовлені історичними, політичними, націоментальними процесами.

Ключові слова: концепт мир, вільний асочฺіативний експеримент, психолінгвістичний аналіз, лексичний аналіз.

\section{Introduction}

In modern linguistics, the research based on the word association tests has become rather popular. Reflecting the world in the mind of native speakers, experimental studies provide rather valuable information for the analysis of certain mental fragments. They also help reveal verbal markers of the concepts, establish semantic fields, that reflect a certain area of the person's inner world and reveal 
peculiarities of perception and comprehension of lexical units and in total they serve as the material to build a linguistic image of the world.

Building associations is a complicated psychological and physiological process, which presupposes connection between particular neurological and mental activities, thoughts, ideas, feelings. Certain images that are fixed in the native speakers' subconscious are the result of the powerful mechanism of associative connections to a particular word that is articulated, heard or read. Perception of the world and individual style of a person are manifested through person's associations and through the prism of one's individual associative image of the world, that has been formed during one's period of maturing in a certain social, cultural, mental, and linguistic environment.

The idea of studying lexical semantics using associative approach was introduced by Leontyev (1969). The researcher mainly focused on principal unity of psychological nature of semantic and associative characteristics of words (Leontyev, 1969). According to Martinek, using theoretical apparatus of cognitive linguistics to interpret the results of word association tests provides a new perspective for the classification of associative responses. The main task of a researcher is not in creating an artificial classification of the received responses, but in reconstructing the respective conceptual structures in the speaker's mind (Martinek, 2011).

In scientific works of recent years, due to association tests, vectors of associations as indicators of changes in the native speakers' mind have been characterized (Alimushkina, 2015); types of verbal connections in associative fields have been defined (Terekhova, 2014; Martynovych, 1989; Horoshko, 2001), certain concepts that belong to different semantic spheres have been analysed (Nedashkivska, 2011; Denysevych, 2011), comparative research has been carried out: results of various word association tests conducted at different times have been compared to define the structure and dynamics of concepts (Zayets, 2010), etc.

In recent years, scholarly works that scrutinize the ontology of war and peace in the context of Christianity and Islam (Semchynski, 2007), from the point of view of linguistic information space of the present, have aroused interest (Building, 2015; Paraknonski \& Yavorska, 2019), philosophical evaluative paradigm of linguistic means of defining the concepts of War and Peace in modern media has been analysed (Kots, 2019), the concept of Peace has been characterized from the point of view of cognitive linguistics (Khudolii, 2014), associative fields of the word-stimulus "Peace" in East Slavic languages have been analysed (Terekhova, 2014).

In modern world the ontology of war and peace belongs to the timeless problems of struggle of opposites in human life. In human mind war is always associated with aggression, destruction, disaster, death, whereas peace is associated with calm, construction, life. Semantics of these opposing concepts is reflected in modern explanatory dictionaries (see War: "1. Organised armed struggle between 
states, nations or armed groups within a country. 2. Fig. A state of hostility between anybody; argument, quarrel with somebody, struggle") (SUM-11, I: 669) and Peace: "1. No disagreement, hostility, argument; consent (in $4^{\text {th }}$ mean.). 2. No armed struggle between two or more nations, states; opposite war. 3. Compromise between the fighting sides to cease fire; peace treaty. 4. Calm, silence" (SUM-11, IV: 712); War "1. Organised armed struggle between states, social layers, etc. 2. Fig. A state of hostility between anybody; argument, quarrel with somebody, struggle" (VTSSUM: 186) and Peace "1. No disagreement, hostility, argument; consent (in $4^{\text {th }}$ mean.). 2. No armed struggle between two or more nations, states; opposite war. 3. Compromise between the fighting sides to cease fire; peace treaty. 4. Calm, silence" (VTSSUM: 667); War 1. Organised armed struggle between states, nations or armed groups within a country. 2. Fig. A state of hostility between anybody; argument, quarrel with somebody, struggle (SUM-20, III: 469) and Peace 1. No disagreement, hostility, argument; consent (in 4th mean.). 2. No armed struggle between two or more nations, states; opposite war. 3. Compromise between the fighting sides to cease fire; peace treaty. 4. Calm, silence (in mean. 13)" (SUM-20, IX: 1621). As we see, the meanings of the lexical units under analysis in reputable explanatory dictionaries of the Ukrainian language mainly coincide. It is worth mentioning that these concepts acquire new semantic shades, get new connotations and evaluative paradigms at the present historic moment.

Today's war in Ukraine differs greatly from previous traditional world wars. If the main purpose of wars and military operations in the past was to achieve the military goal using physical activities (destruction, occupation, etc.), physical military operations and their results affected cognitive sphere, i.e. the sphere of understanding and comprehension of reality. Nowadays it is vice versa - the war as physical violence aims at affecting human conscience, their behavior (Building, 2015). Today's war in Ukraine is mainly a powerful information war, "the war in minds and for minds. It is the war for cognitive and communication control, for power over human mind, their emotions, thinking, and consequently, for their behavior. It is the struggle for dominance of certain ideas about the world and events in social and individual environment and simultaneous destruction of opposite, "hostile" opinions and thoughts" (Parakhonsky, 2019, p. 21), "it is quasiaggressive tool of peaceful life, not only of armed conflict between states. And sustainable development of information space produces new opportunities for using these tools. The Internet enabled it to reach new peaks" (Pocheptsov, 2015, p. 3).

Despite the considerable amount of scientific works of philosophical and historical nature on the ontology of war and peace, the variety of approaches to study these linguistic units from the point of view of cognitive linguistics, sociolinguistics, communicative pragmatic linguistics, etc., the issue of dominant and peripheral ideas of these concepts in native speakers' minds has not been researched enough. This fact contributes to the topicality and prospects of our research. In the context of tough competitive struggle in modern politics, business, 
economy and social life the concept of Peace acquires some new sense and requires integral systemic description from the perspective of word association test.

The purpose of our research is to carry out integral psycholinguistic analysis of the concept of Peace verbal markers and to compare its associative and lexical meanings at the present stage of the Ukrainian language development. The stated purpose presupposes solution of the following tasks: 1) on the basis of the responses received in word association test to single out and characterize lexical semantic groups which model the lexical semantic field of the word-stimulus peace; 2) to define dominant ideas of the respondents and unconscious components of the concept of Peace semantic space to the maximum extent possible; 3) to analyse the received responses according to grammar criterion; 4) to compare the results of psycholinguistic and lexicographic descriptions of the word meaning.

We support the opinion of some scholars to differentiate these two types of meanings in terms of terminology - the ones recorded in explanatory dictionaries, and the ones represented in native speakers' minds (Popova \& Sternin, 2007, p. 66).

According to Popova and Sternin, the systemic lexicographic meaning has been formed in two ways - logically and descriptively. The logical method is connected to the attempts of lexicographers to minimize the features of a certain word meaning. The descriptive method relies on the limited volume of a dictionary entry. Lexical meanings recorded in dictionaries usually form the nucleus of a word meaning. Those semantic features that are not recorded in dictionary entries but are regularly represented in the contexts of a word usage make it possible to state that there are some additional shades in a word meaning, peripheral, potential ones, and confirm the existence of psychologically real (or psycholinguistic) meaning of the word (Popova \& Sternin, 2007, p. 67).

The psychological meaning of the word is a structured unity of all semantic components virtually connected to a certain sound representation in native speakers' minds. This is the volume of semantic components that is activated in native speakers' minds by a word taken in isolation, in a unity of all its semantic properties - more or less bright, nuclear and peripheral ones (Popova \& Sternin, 2007, p. 68).

A psychologically real word meaning may be theoretically defined and characterized in its basic properties due to comprehensive analysis of all recorded contexts of the word usage. In addition, it may also be effectively defined in an experimental way - though the prism of psycholinguistic experiment.

\section{Methods and Procedure}

Representatives of different linguistic schools (Sternin \& Rudakova, 2001; Cremers \& Chemla, 2016; Rakosi, 2017) are actively working on elaboration and improvement of psycholinguistic analysis methodology. Semantic space construction using word association test by college students has been studied in the 
works (El-Dakhs, Goldfarb, Halpern, Kostruba, Kotys, Letiucha, Oleksandr Petrov, Vadym Zavadsky). The free WAT is one of the most efficient ways to describe concepts. It enables to define the biggest amount of concept features typical for the current state of native speakers' mind (Kriuchkova, 2005; Kurhanova, 2019; Vivas, Manoiloff, García, Lizarralde, \& Vivas, 2019).

Free word association test presupposes that respondents are given a list of words-stimuli to get quick association responses. According to the requirement of the test the associative reply-response should follow at once, without taking time to think, because if there is choice, there is no association process in the sense traditionally accepted in psychology (Frumkina, 2003). It is important to emphasize that free word association test does not restrict the choice of responses by any criterion and presupposes no limits of verbal reactions. Thus, in most cases respondents give not one, but two or even more responses to the word-stimulus. According to Martinek, "second, third, etc. responses, which are usually not recorded in associative dictionaries, also comprise important information which may be used, in particular, to explicate corresponding conceptual structures in speakers' mind" (Martinek, 2007, p. 14).

To carry out psycholinguistic diagnostics of the concept of Peace verbal markers we have conducted free word association test which has been performed in writing. 148 respondents have been engaged in the experiment (first and secondyear students of Faculty of Philology and Journalism, Lesya Ukrainka Volyn National University - native speakers of Ukrainian), aged 18-20. To analyse associations there has been elaborated an express questionnaire. The questions have been connected to the word-stimulus Peace and its association field - words related to the word-stimulus. No refusals have been recorded. In this article we only focus on direct responses received to the word-stimulus Peace. Results of other types of reactions, such as phonetic, derivational, phraseological will be analysed in our further research.

At the same time, in order to achieve objective results, we have combined psycholinguistic and lexicographic data for verbal representation of the concept. To fulfill this we have also utilized the following methods: observation of linguistic data, descriptive method with its techniques of systemic comprehensive study of associative and lexical meanings of the concept of Peace; psycholinguistic analysis - to define emotional responses of a person to the given word-stimulus; contextual analysis - to study extralinguistic factors, from the perspective of which verbal markers of the concept of Peace have been characterized; component analysis - to differentiate the received words-reactions into semantic groups, etc.

\section{Results and Discussion}

Taking into account the traditional conditions under which word association test has been carried out, where only the first answer is taken into consideration, the number of the responses received to the word-stimulus coincides with the number 
of respondents (148). As 105 words- responses have been received- 329 wordtokens - responses to the word-stimulus peace, we have decided to present them in full. It enabled us to reproduce the system of associations, created by the analysed word-stimulus: calm (реасе) /спокій 59, peace of mind / спокій (на, в) душі 5, peace of mind / душевний спокій 3 , peace in the country / спокій в краӥні 2 , peace in the state / спокій в державі 2, harmony / злагода 27, friendship / дружба 18, happiness / щастя 16, silence / тиша 8, love / любов 8, consent / згода 8, kindness / добро 7, agreement / порозуміння 7, harmony / лад 6, rapport / взаєморозуміння 6, dove / голуб 6, по war /відсутність війни 5, safety / безпека 5, joy / радість 5, sun / сонще 5, light / світло 5, life / життя 5, blessing / благодать 3, harmony / гармонія 3, smile / посмішка 3, welfare / благополуччя 3, tears of јоу / сльози радості 3, tears / сльози 2, freedom / свобода 2, support / підтримка 2, friendliness / дружелюбність 2, balance / рівновага 2, cosiness / затишок 2, solidity / міџність 2, strength / сила 2, commonwealth / співдружність 2, laughter / сміх 2, angel / ангел 2, holiday / свято 2, God / Бог 2, bird / nтах 2, family / родина 2, hapру family / щзаслива родина, all family / вся родина, child / дитина 2, smiling child / усміхнена дитина, happy child / щаслива дитина, тот / мама, haрру тот / щзаслива мама, granny / бабуся, sky / небо 2, clear sky / чисте небо, cloudless sky / безхмарне небо, bright sky / світле небо, stability / стабільність, humanity / людяність, justice / правосуддя, decеnсу / порядність, liberty / воля, independence / незалежність, prosperity / добробут, confidence / впевненість, warmth / тепло, compromise / компроміс, reconciliation / примирення, comfort / комфорт, mutual respect / взаємоповага, truсе / перемир'я, tranquility / умиротворення, реасеfulness / миролюбство, soul / душа, consolation / втіха, eternity / вічність, defender / захисник, cat / кim, in a friendly way / дружно, joyfully / padiсно, peacefully / спокійно, trust / довіра, field / поле, deтоnstration / демонстрація, Independence Day / День незалежності, Minsk Agreements / Mінські угоди, yellow and blue flag / жовто-блакитний прапор, willow / верба, guilder rose / калина, bread / хліб, salt / сіль, chewing guт / жувачка, super! / cynep!, wahey! / клас!, cool! / сила!, Ukraine / Україна, Lord / Господь, Mother of God / Божа Mати, The Son of God / Син Божий, Holy Spirit / Святий Дух, grace of the Lord / благодать Господня, playground / дитячий майданчик, flowers are in bloom / квіти ивітуть, greens abound / зелень буяє, birds are singing / nтахи співають, doves are flying / голуби літають, cheerful people are walking around the city / веселі люди гуляють по місту, child is running along the path / дитина біжить стежкою. Out of the abovementioned responses, 44 have been used two times or more (from 2 to 59 times -268 word-tokens in total), 61 have been used only one time.

The analysis of the responses received has enabled us to define the most frequent ones, out of which the lexeme-association calm (peace) / спокій $\mathbf{5 9}$ is dominant. Sometimes its semantics is concretized using nouns or adjectives, such 
as peace of mind / спокій (на, в) душі 5, peace of mind / душевний спокій 3, реасе in the country / спокій в країні 2 , реасе in the state / спокій в державі 2 . Besides, for 8 respondents peace is associated with silence / тиша, for 3 of them - with blessing / благодать, for 1 - with tranquility / умиротворення, which are semantically close to the word calm (реace) / спокіü. It is worth mentioning that such associations to the word-stimulus peace coincide with one of its lexical meanings, recorded in dictionaries (see peace / mup in $4^{\text {th }}$ meaning - its "calm (peace), silence"(SUM-11, IV: 712; VTSSUM : 667; SUM-20, IX: 1621).

The following responses are quite frequent: harmony / злагода 27, friendship / дружба 18, love / любов 8, consent / згода 8, agreement / порозуміння 7, harmony / лад 6, rapport / взаєморозуміння 6, which directly or indirectly correlate with the first lexical meaning of the word-stimulus (see peace "1. No disagreement, hostility, argument; consent (in $4^{\text {th }}$ mean.) " (SUM-11, IV: 712; VTSSUM: 667; SUM-20, IX: 1621). The unique responses mutual respect, trust, support, friendliness are semantically close to these words.

The second lexical meaning of the word-stimulus peace, namely "2. No armed struggle between two or more nations, states; opposite war" (SUM-11, IV: 712; VTSSUM: 667; SUM-20, IX: 1621) is directly or indirectly related to the following responses of the respondents: nо war / відсутність війни 5, safety / безпека 5, life / життя 5, соттопwealth / співдружність 2, stability, welfare / стабільність, благополуччя 3, prosperity / добробут, confidence / впевненість, decency / порядність, independence / незалежність, liberty / воля. The third lexical meaning of the word-stimulus peace, namely " 3 . Compromise between the fighting sides to cease fire; peace treaty" (SUM-11, IV: 712; VTSSUM: 667; SUM-20, IX: 1621) can be traced in the following non-repetitive responses: truce / перемир'я, reconciliation / примирення, сотрromise / компроміс, Minsk Agreements / Мінські угоди. Other responses of the respondents are not related to the lexical meanings recorded in dictionaries: happiness / щастя 16, kindness / добро 7, harmony / гармонія 3, соzіnеss / затишок 2, јоу / радість 5, consolation /втіха, holiday / свято 2, light / світло 5, warmth / тепло, sun / сонце 5, smile / посмішка 3, laughter / сміх 2, tears / сльози 2, joyfully / радісно, in a friendly wаy / дружно, реacefully / спокійно. It is worth mentioning that those are emotional evaluative lexemes with positive connotation.

Responses that belong to a specific type of the word-sentence are sporadic. In Ukrainian linguistics units of this type have been classified as "non-segmented exclamations-sentences" (Vykhovanets, 2004, p. 374), which indirectly correlate with utterances. They do not define extralinguistic situations, but only render emotions and feelings of the speaker that are related to such situations, or express their subjective positive or negative assessment: super! / cynep!, wahey! / клас!, cool! / сила!

Semantically distant associations correlate with the names of concrete concepts: sky / небо 2, angel / ангел 2, тот / мама, God / Бог 2, bird / nmax 2, 
family / родина 2, child / дитина 2, defender / захисник, cat / кim, field / поле, demonstration / демонстрачія, Independence Day / День незалежності, blue and yellow flag / жовто-блакитний прапор, granny / бабуся, Lord / Господь, Mother of God / Божа Мати, The Son of the God / Син Божий, Holy Spirit I Святий Дух, Ukraine / Україна, willow / верба, guilder rose / калина, bread / хліб, salt / сіль, chewing gит / жувачка; abstract concepts: eternity / вічність, soul / душа, humanity / людяність, јustice / правосуддя, solidity / міџність, strength / сила; syntactic structures: clear sky / чисте небо, cloudless sky / безхмарне небо, bright sky / світле небо, smiling child / усміхнена дитина, happy child / щаслива дитина, hарру тот / щаслива мама, happy family / щаслива родина, all family / вся родина, playground / дитячий майданчик, flowers are in bloom / квіти цввітуть, greens abound / зелень буяє, birds are singing / птахи співають, doves are flying / голуби літають, cheerful people are walking around the city / веселі люди гуляють по мicmy, child is running along the path / дитина біжить стежкою. These associations do not correlate with any of the lexical meanings of the word-stimulus, recorded in the dictionaries. We believe that their sense connection with the word-stimulus peace can be traced at the unconscious level, which reflects psycholinguistic meaning of this word. The association chewing gит / жувачка, which seems to be absurd as it has no relation to the word-stimulus, needs to be clarified. When used in the appropriate context: peace, friendship, chewing gum (a Ukrainian idiomatic expression) / мир, дружба, жувачка - it acquires additional semantic shades. It should be mentioned that in such association line it is used in colloquial speech.

Thus, outlining respondents' dominant ideas and defining unconscious components of the concept of Peace semantic space, we mainly focused on the frequency of responses to the respective word-stimulus and correlation of its associative and lexicographic meanings.

The results of free word association test to some extent correlate with the responses to the word-stimulus peace, recorded in Words Associations Network, such as disarmament, tranquility, treaty, prosperity, quiet, accord, reconciliation, negotiation, ceasefire, , truce, peacekeeping, justice, armistice, goodwill, mediation, serenity, overture, envoy, righteousness, loving, breach, harmony, strife, discord, bloodshed, endowment, stability, diplomacy, hostility, happiness, agreement, conflict, reparation, neutrality, allies, mediator, aggression, pledge, unity, war, everlasting, perpetual, peaceful, loving, humanitarian, negotiate, war, disturb, reaffirm, restore, ratify (Words Associations Network).

The abovementioned confirms the opinion of Popova \& Sternin (2008) that the psycholinguistic meaning of a word is wider and more extensive than its lexicographic one which "is generally included in psychologically real meaning" (Popova \& Sternin, 2007, p. 68), though its components may occupy different places in the psycholinguistic meaning based on their intensity. 
The analysis of the responses received in this word association test has been carried out according to the grammar criterion which presupposes their division into pragmatic and syntagmatic. 21 associations belong to syntagmatic ones: peace

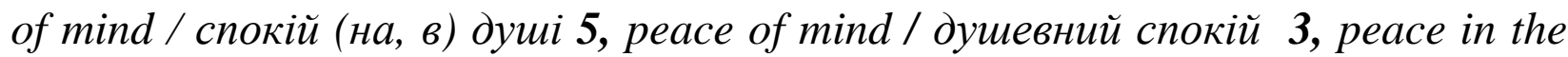
country / спокій в краӥні 2, peace in the state / спокій в державі 2, по war / відсутність війни 5, tears of јоу / сльози радості 3, clear sky / чисте небо, cloudless sky / безхмарне небо, bright sky / cвimле небо, happy family / щзаслива родина, all family / вся родина, hарру тот / щаслива мама, smiling child / усміхнена дитина, happy child / щзаслива дитина, playground / дитячий майданчик, flowers are in bloom / квіти ивітуть, greens abound / зелень буяє, birds are singing / птахи співають, doves are flying / голуби літають, cheerful people are walking around the city / веселі люди гуляють по місту, child is running along the path / дитина біжить стежкою. Six syntagmatic responses occurred more than once (from two to five times - 20 word-tokens in total), 15 responses have been given only one time. Syntagmatic associations constitute $10.64 \%$ of the total number of all responses analysed. We believe they prove figurative worldview of the respondents, reflected in the individual picture of the world.

All other associations that we received on the analysed word-stimulus belong to paradigmatic ones: calm (реасе) / спокій 59, harmony / злагода 27, friendship / дружба 18, happiness / щастя 16, silence / тиша 8, love / любов 8, consent / згода 8, kindness / добро 7, agreement / порозуміння 7, harmony / лад 6, rapport / взаєморозуміння 6, dove / голуб 6, safety / безпека 5, јоy / радість 5, sun / сонце 5, light / світло 5, life / життя 5, harmony / гармонія 3, smile / посмішка 3, godsend / благодать 3, welfare / благополуччя 3, tears / сльози 2, sky / небо 2, freedom / свобода 2, support / підтримка 2, friendliness / дружелюбність 2, balance / рівновага 2, coziness / затишок 2, solidity / міџність 2, strength / сила 2, соттопwealth / співдружність 2, laughter / сміх 2, angel / ангел 2, тот / мама, holiday / свято 2, God / Бог 2, bird / nmax 2, family / родина 2, child / дитина 2, stability / стабільність, huтапity / людяність, јustice / правосуддя, decепсу / порядність, liberty / воля, independence / незалежність, prosperity / добробут, confidence / впевненість, warmth / тепло, coтpromise / компроміс, reconciliation / примирення, comfort / комфорт, титиаl respect / взаємоповага, truсе / перемир'я, tranquility / умиротворення, реacefulness / миролюбство, soul / душа, consolation / втіха, eternity / вічність, defender / захисник, cat / кim, in a friendly way / дружно, joyfully / радісно, реасеfully / спокійно, trust / довіра, field / nоле, demonstration / демонстрація, granny / бабуся, willow / верба, guilder rose / калина, Ukraine / Україна, Lord / Господь, Mother of God / Божа Maти, The Son of God / Син Божий, Holy Spirit / Святий Дух, Minsk Agreements / Мінські угоди, Independence Day / День незалежності, yellow and blue flag / жовтоблакитний прапор, grace of the Lord / благодать Господня, bread / хліб, salt / 
сіль, chewing guт / жувачка, super! / cynер!, wahey! / клас!, cool! / сила! Wе have singled out 84 words-associations of this type (a significant part of them have been used more than once: from 2 to 59 times, 294 word-tokens altogether), which constitute $89.36 \%$ of the total of all responses analysed. They are all nouns, with a few exceptions, i.e. they belong to the same part of speech as the word-stimulus. Predominance of paradigmatic grammatical associations represents students' analytical and integrated thinking.

The associations on the word-stimulus peace make up 11 lexical semantic groups to denote: 1) the state of environment, people's inner world, their physical, emotional and mental state: calm (реасе) / спокій 59, cosiness / затишок 2, silence / тиша 8, godsend / благодать 3, balance / рівновага 2, light / світло 5, warmth / тепло, peace of mind / спокій (на, в) душі 5, peace of mind / душевний спокій 3, happiness / щастя 16, love / любов 8, kindness / добро 7, harmony / гармонія 3, joy / радість 5, consolation / втіха, smile / посмішка 3, laughter / сміх 2, tears / сльози 2; tears of јоу / сльози радості 3, tranquility / умиротворення, сопfidence / впевненість, life / життя 5, solidity / міцність 2, strength / сила 2, humanity / людяність, decеnсу / порядність, joyfully / радісно, peacefully / спокійно, in a friendly жаy / дружно; 2) relations between people, nations, states, etc.: harmony / злагода 27, consent / згода 8, friendship / дружба 18 , peace in the country / спокій в країні 2 , реасе in the state / спокій в державі 2, по war / відсутність війни 5, safety / безпека 5, agreement / порозуміння 7, harmony / лад 6, rapport / взаєморозуміння 6, support / підтримка 2, friendliness / дружелюбність 2, coтmопwealth / співдружність 2, stability / стабільність, independence / незалежність, prosperity / добробут, сотрroтise / компроміс, reconciliation / примирення, comfort / комфорт, mитиаl respect / взаємоповага, truce / перемир'я, реасеfulness / миролюбство, trust / довіра, welfare / благополуччя 3; 3) family relations and people based on the functions they perform: defender / захисник, family / родина 2, happy family / щаслива родина, all family / вся родина, child / дитина 2, smiling child / усміхнена дитина, happy child / щаслива дитина, тот / мама, hарру тот / щзаслива мама, granny / бабуся; 4) confessional nominations: Lord / Господь, angel / ангел 2, grace of the Lord / благодать Господня, God / Бог 2, soul / душа, eternity / вічність, Mother of God / Божа Maтu, the Son of God / Син Божий, Holy Spirit / Святий Дух; 5) flora and fauna: bird / nmax 2, dove / голуб 6, cat / кim; willow / верба, guilder rose / калина; 6) space concepts: Ukraine / Украӥна, playground / дитячий майданчик, field / поле; 7) cosmological concepts: sun / соние 5; sky / небо 2, clear sky / чисте небо, cloudless sky / безхмарне небо, bright sky / світле небо; 8) social political and state concepts: liberty / воля, freedom / свобода 2, justice / правосуддя, holiday / свято 2, demonstration / демонстраиія, Independence Day / День Незалежності, yellow and blue flag / жовто-блакитний прапор, Minsk Agreements / Мінські угоди; 9) household nominations: bread / хліб, salt / сіль, chewing guт / жувачка; 10) statements: Flowers are in bloom / Квіти 
ивітуть, Greens abound / Зелень буяє, Birds are singing / Птахи співають, Doves are flying / Голуби літають, Merry people are walking around the city / Веселі люди гуляють по місту, Child is running along the path / Дитина біжить стежкою; 11) speaker's feelings and emotions that correlate with nonsegmented exclamations-sentences: Super! / Cynер!, Wahey! / Клас!, Cool! / Cила!

Thus, the detailed analysis of the received associations made it possible to single out 11 lexical semantic groups, out of which the most numerous responses are connected with the state of environment, people's inner world, their physical, emotional and mental state, moral and ethic properties (155 word-tokens $-47.1 \%$ ). A significant part of the respondents associates peace with "calm (peace)". In this association line we have also defined non-typical responses: confidence / впевненість, life / життя, joyfully / радісно, in a friendly way / дружно, peacefully / спокійно, etc., related to students' personal experience.

The next largest group of associations directly connected to relations between people, nations, states (105 word-tokens - $31.9 \%)$. Repetitive responses are harmony / злагода, consent / згода, friendship / дружба, agreement / порозуміння, harmony / лад, rapport / взаєморозуміння, etc., non-repetitive ones are as follows: mutual respect / взаємоповага, independence / незалежність, stability / стабільність, welfare / благополуччя, reconciliation / примирення, truсе / перемир'я, etc.

Non-typical responses are the ones that comprise lexemes to denote family relations and people based on the functions they perform: family / родина, child / дитина, тот / мама, granny / бабуся, smiling child / усміхнена дитина, etc. (12 word-tokens - $3.6 \%$ ); confessional nominations: Lord / Гocnodb, grace of the Lord / благодать Господня, God / Бог, the Son of God / Син Божий, etc. (11 word-tokens - $3.3 \%$ ); nominations of flora and fauna: dove / голуб, cat / кim; willow / верба, guilder rose / калина, etc. (11 word-tokens - 3.3\%); space concepts: Ukraine / Украӥна, playground / дитячий майданчик, field / поле (3 word-tokens - $0.9 \%$ ); cosmological concepts: sun / сонце, sky / небо, clear sky / чисте небо, cloudless sky / безхмарне небо, etc. (10 word-tokens - 3.0\%); sociopolitical and state concepts: demonstration / демонстрація, Independence Day / День Незалежності, yellow and black flag / жовто-блакитний прапор, Minsk Agreements / Мінські угоди, etc. (10 word-tokens - 3.0\%); household nominations: bread / хлiб, salt / ciль,etc. (3 word-tokens - 0.9\%); statements: Flowers are in bloom / Kвіти uввітуmь, Merry people are walking around the city / Веселі люди гуляють по місту, Child is running along the path / Дитина біжить стежкою, etc. (6 word-tokens - $1.8 \%$ ); speaker's feelings and emotions that correlate with non-segmented exclamations-sentences: Super! / Cynep!, Wahey! / Kлас!, Cool / Сила! (3 word-tokens - $0.9 \%$ ) (see Table 1, Figure 1). 
Table 1.

Lexical Semantic Groups of the Word-Stimulus Peace

\begin{tabular}{ll}
\hline Name of the group & $\mathbf{\%}$ \\
\hline State of environment, people's inner world, their physical, emotional and & 47.1 \\
mental state, moral and aesthetic properties & \\
Relations between people, nations, states & 31.9 \\
Family relations and people based on the functions they perform & 3.6 \\
Confessional nominations & 3.3 \\
Flora and Fauna & 3.3 \\
Space concepts & 0.9 \\
Cosmological concepts & 3 \\
Sociopolitical and state concepts & 3 \\
Household nominations & 0.9 \\
Statements & 1.8 \\
Speaker's feelings and emotions that correlate with non-segmented & 0.9 \\
exclamations-sentences &
\end{tabular}

Figure 1.

Lexical semantic groups of the word-stimulus peace

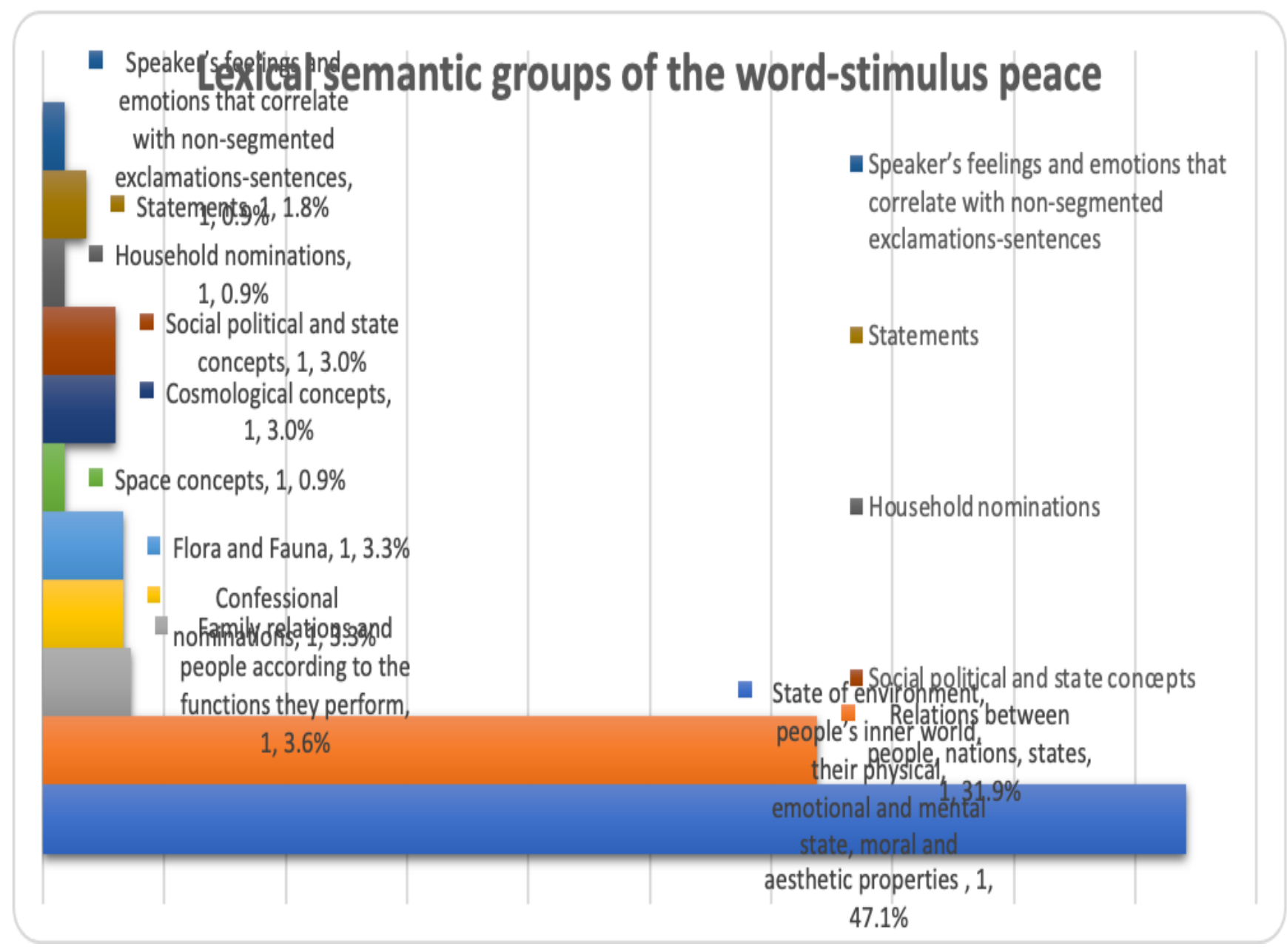


These associations reflect peculiarities of respondents' worldview, individual figurative worldview.

\section{Conclusions}

Psycholinguistic analysis of the concept of Peace verbal markers made it possible to define typical and non-typical respondents' ideas of the word-stimulus peace from the perspective of free word association test. The first responses belong to the dominant ones. They correlate with the lexical meaning of the word-stimulus recorded in modern dictionaries and reflect direct connection between the wordstimulus and associations. The latter ones are non-typical, unconscious elements of the concept of Peace semantic space, that outline personal worldview of the respondents, and they have no relation to the lexical meanings recorded in dictionaries. Their sense connection is possible only at the unconscious level and concerns the psycholinguistic meaning of this word. In the analysed associations paradigmatic responses $(89.36 \%)$ prevail over syntagmatic ones $(10.64 \%)$. On the basis of the received responses lexical associative field of the word-stimulus peace has been modeled and characterized. It includes 11 lexical semantic groups. The most numerous responses are connected to the state of environment, people's inner world, their physical, emotional and mental state, moral and ethic properties $(47.1 \%)$. The next largest group reflects relations between people, nations, states $(31.9 \%)$. Few respondents associate the word-stimulus peace with nominations to denote family relations and people based on the functions they perform (3.6\%); confessional nominations (3.3\%); nominations of flora and fauna $(3.3 \%)$; space concepts $(0.9 \%)$; cosmological concepts $(3.0 \%)$; social political and state nominations (3.0 \%); household nominations (0.9 \%); statements $(1.8 \%)$; speaker's feelings and emotions $(0.9 \%)$. These associations reflect personal experience and peculiarities of respondents' worldview. We see the prospects of this research in the in-depth analysis of associative fields of the words connected to the word-stimulus peace through the prism of psychological and linguistic factors.

\section{References}

Алимушкина О. А. Векторы ассоциирования как индикаторы изменения сознания носителей русского языка. Филологические науки. Вопросы теории и практики. 2015. №6(48). Ч.1. С.17-19.

Вихованець І., Городенська К. Теоретична морфологія української мови. Академічна граматика украӥнської мови / За ред. І. Вихованця. Київ: Унів. вид-во «Пульсари», 2004. $400 \mathrm{c}$.

Горошко Е. И. Интегративная модель свободного ассоциативного эксперимента. Харьков : Изд. Группа «РА - Каравелла», 2001. 320 с.

Заєць І. Г. Структура та динаміка асоціативних полів лексем дівчина, жінка, хлопець, чоловік. Вісник Дніпропетровського університету. Серія «Мовознавство». 2010. Вип. 16. № 11. С. 127-133.

Коць Т. Онтологія війни й миру в мовно-інформаційному просторі сьогодення. Культура слова. 2019. № 90. С. 132-149.

Крючкова Н. В. Лингвокультурное варьирование концептов. Саратов: Научная книга. 2005. $164 \mathrm{c}$. 
Курганова Н. И. Ассоциативный эксперимент как метод исследования значения живого слова. Вопросы психолингвистики. 2019. 3(41). 24-37. https://doi.org/10.30982/20775911-2019-41-3-24-37

Леонтьев А. А. Язык, речь, речевая деятельность. Москва: Просвещение, 1969. 214 с.

Мартинович Г. А. Вербальные ассоциации и организация лексикона человека. Филологические науки, 1989. № 3. С. 39- 45.

Мартінек С. Емпіричні й експериментальні методи у сучасній когнітивній лінгвістиці. Вісник Львівського університету. Серія філологічна. Львів: Вид-во ЛНУ, 2011. Вип. 52. C.25-32.

Парахонський Б., Яворська Г. Онтологія війни і миру: безпека, стратегія, смисл. Київ: НІСД, 2019. $560 \mathrm{c.}$

Попова З. Д., Стернин И. А. Когнитивная лингвистика. Москва: Восток-Запад. 2007. 315 с.

Почепцов Г. Сучасні інформаційні війни. Київ: Вид. дім «Києво-Могилянська академія», 2015. $497 \mathrm{c}$.

Семчинський К. В. Війна і мир у християнстві та ісламі. Київ: Міленіум, 2007. 164 с.

Стернин И. А, Рудакова А. В. Психолингвистическое значение слова и его описание. Теоретические проблемы: монография. Saarbrücken: LAP Lambert Academic Publishing. 2011. 192 c.

Худолій А. Вербальне вираження концепту «мир» у політичних промовах американських президентів. Науковий вісник Міжнародного гуманітарного університету. Серія: Філологія. 2014. № 10. том 1. С. 194-197.

Фрумкина Р. М. Психолингвистика. Москва: Академия, 2003320 с.

Abdel Salam El-Dakhs, D. (2017). The effect of language exposure and word characteristics on the Arab EFL learners' word associations. Journal of Psycholinguistic Research, 46(4), 1033-1052. https://doi.org/10.1007/s10936-017-9477-z

Goldfarb, R., \& Halpern, H. (1984). Word association responses in normal adult subjects. Journal of Psycholinguistic Research, 13(1), 37-55. https://doi.org/10.1007/BF01067901

Cremers, A., \& Chemla, E.A. (2016). A psycholinguistic study of the exhaustive readings of embedded questions. Journal of Semantics, 33(1), 49-85. https://doi.org/10.1093/jos/ffu014

Rakosi, C. (2017). Replication of psycholinguistic experiments and the resolution of inconsistencies. Journal of Psycholinguistic Research, 46(5), 1249-1271. https://doi.org/10.1007/s10936-017-9492-0

Vivas, L., Manoiloff, L., García, A., Lizarralde, F., \& Vivas, J. (2019). Core semantic links or lexical associations: assessing the nature of responses in word association tasks. Journal of Psycholinguistic Research, 48, 243-256. https://doi.org/10.1007/s10936-018-9601-8

\section{Sources}

Великий тлумачний словник сучасної української мови (з дод. і допов.) / Уклад. і гол. ред. В. Т. Бусел. Київ; Ірпінь: ВТФ «Перун», 2005. 1728 с.

Мартінек С. В. Український асоціативний словник: У 2 т. Т. 1. Від стимулу до реакції. Львів: Видавничий центр ЛНУ імені Івана Франка, 2007. 351 с.

Словник української мови: в 11-ти т. Київ: Наукова думка, 1970-1980.

Словник української мови: в 20-ти т. Київ: Наукова думка, 2010. Retrieved from: https://services.ulif.org.ua/expl/Entry/index?wordid=51087\&page $=1620$

Word Associations Network. Retrieved from: https://wordassociations.net/en/words-associatedwith/peace?button=Search

\section{References (translated and transliterated)}

Abdel Salam El-Dakhs, D. (2017). The effect of language exposure and word characteristics on the Arab EFL learners' word associations. Journal of Psycholinguistic Research, 46(4), 1033-1052. https://doi.org/10.1007/s10936-017-9477-z 
Alimushkina, O. A. (2015). Vektory associirovaniia kak indicatory izmeneniia soznaniia nositelei russkogo iazyka. [Vectors of association process as indicators of Russian native speakes altered state of consciousness]. Philologicheskiie nauki. Voprosy teorii i praktiki, 6(48), 1, 17-19.

Cremers, A., \& Chemla, E.A. (2016). A psycholinguistic study of the exhaustive readings of embedded questions. Journal of Semantics, 33(1), 49-85. https://doi.org/10.1093/jos/ffu014

Frumkina, R. M. (2003). Psicholingvistika. [Psycholinguistics]. Moscow: Akademiya.

Goldfarb, R., \& Halpern, H. (1984). Word association responses in normal adult subjects. Journal of Psycholinguistic Research, 13(1), 37-55. https://doi.org/10.1007/BF01067901

Goroshko, Ye. (2001). Integrativnaiia model svobodnogo asotsiativnogo eksperimenta. [Integration model of the free association test]. Kharkiv: RA - Karavella.

Khudolii, A. (2014). Verbalne vyrazhennia kontseptu "myr" u politychnykh promovakh amerykanskykh prezydentiv. [The concept of "peace" verbal representation in the speeches of American Presidents]. Naukovy visnyk Mizhnarodnoho humanitarnoho universytetu. Seriia : Filolohiia, 10(1), 194-197.

Kots, T. (2019). Ontolohiia viyny I myru d movno-informatsiynomu prostori siohodennia. [Ontology of war and peace in modern linguistic information space]. Kultura slova, 90, 132-149.

Kriuchkova, N. V. (2005). Lingvokulturnoie varyirovaniie kontseptov. [Linguistic cultural variety of concepts]. Saratov: Nauchnaia kniga.

Kurganova, N. I. (2019). Asotsyativnyi eksperiment kak metod issledovaniia znacheniia zhyvogo slova. [Association test as the method to analyse the meaning of a word of mouth]. Journal of Psycholinguistics, 3(41, 24-37). https://doi.org/10.30982/2077-5911-2019-41-3-24-37

Leontyev, A. A. (1969). Yazyk, Rech, Rechevaia Deiatelnost. [Language, Speech, Speech Activity]. Moscow: Prosveshcheniie.

Martinek, S. (2011). Empirychni y elsperymentalni metody u suchasniy kohnityvniy linhvistytsi. [Empirical and experimental methods in modern cognitive linguistics]. Visnyk of Lviv Universyty. Seriia Filolohichna, 52, 25-32.

Martynovych, G. A. (1989). Verbalyie asotsiatsii i organizatsiia leksikona cheloveka. [Verbal associations and human lexicon orfanisation]. Fililogicheskiie Nauki, 3, 39-45.

Parakhonsky, B., Yavorska, H. (2019). Ontolohiia viyny I myru: bezpeka, stratehiia, smysl. [Ontology of war and peace: safety, strategy, sense]. Kyiv: NISD.

Pocheptsov, H. (2015). Suchasni informatsiyni viyny. [Modern information wars]. Kyiv: KyivMohyla Academy.

Popova, Z. D., Sternin, I. A. (2007). Kognitivnaya Lingvistika. [Cognitive linguistics]. Moscow: Vostok-Zapad.

Rakosi, C. (2017). Replication of psycholinguistic experiments and the resolution of inconsistencies. Journal of Psycholinguistic Research, 46(5), 1249-1271. https://doi.org/10.1007/s10936-017-9492-0

Semchynsky, K. V. (2007). Viyna i Myr u khrystyianstvi ta islami. [War and peace in Christianity and Islam]. Kyiv: Milenium.

Sternin, I. A., Rudakova, A. V. (2011). Psicholongvisticheskoye znacheniie slova i ego opisaniye. Teoreticheskiie problem: momografiia. [Psycholinguistic meaning of a word and its description. Theoretical issues: monograph]. Saarbrücken: LAP Lambert Academic Publishing.

Vivas, L., Manoiloff , L., García, A., Lizarralde, F., \& Vivas, J. (2019). Core semantic links or lexical associations: assessing the nature of responses in word association tasks. Journal of Psycholinguistic Research, 48, 243-256. https://doi.org/10.1007/s10936-018-9601-8

Vykhovanets, I., Horodenska, K. (2004). Teoretychna morfolohiia ukrainskoi movy. [Theoretical Morphology of the Ukrainian Language]. In I. Vykhovanets, Ed. Akademichna Hramatyka Ukrainskoii Movy [Academic Grammar of the Ukrainian Language]. Kyiv: Pulsary. 
Zaiets, I. H. (2010). Structura ta dynamika asotsiatyvnykh poliv leksem divchyna, zhinka, khlopets, cholovik. [Structure and dynamics of the lexemes girl, woman, boy, man associative fields]. Visnyk Dnipropetrovskoho universytetu. Seria Movoznavstvo, 16(11), $127-133$.

\section{Sources (translated and transliterated)}

Martinek, S. (2007). Ukrainskyi Asotsiatyvny Slovnyk: In 2 vol. Vol. 1: Vid stymulu do reaktsii. [Ukrainian Associative Dictionary: From Stimulus to Reaction]. Lviv: Lviv University.

Slovnyk ukrainskoi movy (SUM): v 11-ty t. (1970-1980). [The dictionary of the Ukrainian language: in 11 volumes]. Kyiv: Naukova dumka.

Slovnyk ukrainskoi movy (SUM): v 20-ty t. (2010). [The dictionary of the Ukrainian language: in 20 volumes]. Kyiv: Naukova dumka. Retrieved from: https://services.ulif.org.ua/expl/Entry/index?wordid=51087\&page $=1620$

Velyky tlumachny slovnyk suchasnoi ukrainskoi movy (VTSSUM). (2005). [Big explanatory dictionary of the modern Ukrainian language]. Edited by Busel V. T. Kyiv: Irpin: VTF "Perun".

Word Associations Network. Retrieved from: https://wordassociations.net/en/words-associatedwith/peace?button=Search 